DOI https://doi.org/10.30525/978-9934-588-81-5-2.59

\title{
ЄВРОПЕЙСЬКИЙ ДОСВІД ДОСЛІДЖЕННЯ ЕФЕКТИВНОСТІ ГІГІЄНИ РУК МЕДИЧНОГО ПЕРСОНАЛУ ЗАКЛАДІВ ОХОРОНИ ЗДОРОВ'Я
}

\author{
Хандога Е. В. \\ лікар-бактеріолог вищої категорії \\ Відокремлений підрозділ «Василівський міжрайонний відділ \\ ДУ «Запорізький обласний лабораторний иентр \\ Міністерства охорони здоров'я Украӥни» \\ м. Василівка, Запорізька область, Україна \\ Кочин I. В. \\ доктор медичних наук, професор, \\ завідувач кафедри медииини катастроф \\ Д3 «Запорізька медична академія післядипломної освіти» \\ Терехов Р. Л. \\ директор \\ ДУ «Запорізький обласний лабораторний центр \\ Міністерства охорони здоров'я Украӥни»
}

Остапенко А. О.

кандидат фармачевтичних наук,

старший викладач кафедри клінічної лабораторної діагностики

ДЗ «Запорізька медична академія післядипломної освіти»

\section{Царьов В. В.}

завідувач відділенням анестезіології та інтенсивної терапії

Запорізька обласна клінічна дитяча лікарня

м. Запоріжжя, Україна

В передачі збудників внутрішньолікарняних інфекцій (ВЛІ) в закладах охорони здоров'я (3О3) різного профілю істотну роль відіграє шкіра рук медичного персоналу (МП). У численних дослідженнях показано, що шкіра рук МП часто контамінована різними патогенними мікроорганізмами, при цьому видовий склад мікрофлори шкіри рук МП залежить від профілю 303 та відділення, а також характеру виконуваної діяльності. 
В Європі дослідження ефективності засобів для гігієни рук МП складається 3 декількох етапів, на кожному 3 яких для тестування використовуються різні стандарти [1].

На першому етапі всі досліджувані дезінфектанти та антисептичні засоби, незалежно від сфери їхнього застосування, повинні пройти базові тести для оцінювання їхнього бактерицидного (стандарт EN 1040) і фунгіцидного (стандарт EN 1275) ефекту .

Другий етап складається 3 двох кроків. Всі засоби для гігієнічної та хірургічної дезінфекції рук, незалежно від методу їхнього використання (миття або обробка протиранням), проходять суспензійний тест prEN 12054.

Європейський стандарт prEN 12054 суспензійний тест (етап 2 / крок 1). Для проведення цього протоколу використовуються типові штами S. aureus, P.aeruginosa, E.coli, Enterococcushirae. Час експозиції (тобто час контакту антисептика зі шкірою рук) становить 1 хв при тестуванні засобів для гігієнічної дезінфекції (гігієнічного миття або обробки) рук і 5 хв при тестуванні засобів для хірургічної дезінфекції рук.

При дослідженні антисептиків, імовірно здатних тривалий час зберігати свою дію після застосування (тобто мають властивість «залишкової активності»), в деяких факультативних тестах допускається збільшення часу експозиції (додатковий час контакту зі шкірою) на $0,5,1,2,3$ і 4 хв.

Критерії ефективності антисептиків, що використовуються при проведенні prEN 12054 суспензійного тесту:

- зниження кількості бактерій порівняно з вихідним значенням на $3 \lg$ (для гігієнічного миття рук) i $5 \lg$ (для обробки рук протиранням);

- зниження контамінації на $4 \mathrm{lg}$ для Candida albicans (цей критерій у даний час офіційно не затверджений);

- зниження мікробного числа на $4 \mathrm{lg}$ для мікобактерій досягається тільки гігієнічною обробкою (протиранням) рук антисептиком і не спостерігається ані при гігієнічному митті рук, ані при хірургічній дезінфекції рук (цей критерій в даний час також не затверджений);

- зниження вірусного числа на $4 \mathrm{lg}$ щодо певних штамів поліовірусу 1-го типу і штамів аденовірусу 5-го типу - для антисептичних засобів, використовуваних для гігієнічної дезінфекції рук (як для гігієнічного миття рук, так і для обробки рук).

Крок 2 передбачає оцінку ефективності антисептиків за допомогою тестів, як EN 1499 і EN 1500 [2]. Вони являють собою протоколи тестування антисептичних засобів, використовуваних для гігієнічного миття та гігієнічної обробки (протирання) рук відповідно. 
Для проведення протоколу EN 1500 (етап 2 / крок 2) потрібно 12-15 добровольців і 18-24-годинна бульйонна культура E. coli (штам К12). Добровольці миють руки з рідким милом, висушують їх, а потім занурюють до п'ясткових кісток у стандартний бульйон з культурою E. coli на 5 c. Руки виймають 3 бульйону, дозволяють стекти надлишку рідини і висушують на повітрі протягом 3 хв. Для виділення бактерій 3 метою оцінки вихідного мікробного числа кінчики пальців окремо кожної руки занурюють в 10 мл тріптіказосоєвого бульйону, що не містить нейтралізатор, і роблять кругові перемішувальні рухи протягом 60 с. Далі руки виймають з бульйону і обробляють 3 мл тестованого антисептика протягом 30 с відповідно до інструкції. Ця процедура повторюється так, щоб загальний час дезінфекції не перевищував 60 с. Потім обидві руки ретельно промивають проточною водою протягом 5 с і висушують. Кінчиками пальців окремо кожної руки роблять перемішувальні рухи в 10 мл тріптіказосоєвого бульйону, що містить нейтралізатор. Цей бульйон використовують для проведення культурального дослідження з метою отримання кінцевого значення мікробного числа (в $\mathrm{lg})$. Готують розведення бульйону і розливають у чашки. Протягом 3 год на тих самих добровольцях тестується контрольний (референтний) дезінфектант (60\% ізопропіловий спирт) і досліджуваний антисептик. Визначення мікробного числа проводиться через 24 і 48 годин після інкубації культури за температури $36^{\circ} \mathrm{C}$. Для оцінки результату використовується середня кількість колоній, виділених 3 лівої і правої рук. Потім обчислюється величина зниження мікробного числа в $\lg$, яка порівнюється 3 вихідним і кінцевим значенням. Зниження мікробного числа після застосування тестованого препарату повинно бути вище або таке ж, як у контрольного спиртовмісного антисептика.

Вимога Свропейського стандарту EN 1499 (етап 2 / крок 2) полягає в тому, щоб тестований антисептик демонстрував значно більш високу ефективність ( $\mathrm{p}=0,01$ для кожної руки) в порівнянні з миттям рук звичайним (не антисептичним) милом протягом 1 хв. Навпаки, Європейський стандарт EN 1500 вимагає, щоб ефективність тестованого антисептика була значно нижче ( $\mathrm{p}=0,1$ для кожної руки), ніж ефективність гігієнічної обробки $60 \%$ ізопропіловим спиртом протягом 1 хв. Тестовані антисептики для протирання рук, що знижують мікробне число в значно меншій кількості, ніж контрольний спиртовмісний антисептик (знижує мікробне число приблизно на $4 \mathrm{lg}$ ), розглядаються як несумісні зі стандартом.

Європейський стандарт prEN 12791 (етап 2/крок 2) являє собою протокол тестування засобів для хірургічної дезінфекції рук (як для миття, так i для протирання рук). Дослідження проводиться на 
18-20 добровольцях. Для проведення тесту не використовується попередня штучна контамінація шкіри рук бактеріями. Відповідно до вимог тесту досліджуваний антисептик не повинен значно поступатися ефективністю ( $\mathrm{p}=0,1$ для кожної руки) контрольному спиртовмісному антисептику (60\% ізопропіловий спирт, час експозиції - 3 хв). Використовуючи метод поділу кисті на сектори, можна оцінити ефективність антисептичний засіб відразу після застосування і через 3 год. Додаткова (факультативна) вимога для антисептичних засобів, що ймовірно мають «залишкову активність», полягає в тому, що тестований антисептик повинен демонструвати достовірно більш високу активність (сума $\mathrm{p}$ для обох рук - 0,01) порівняно 3 контрольним спиртовмісним засобом через 3 години після застосування.

Необхідно зазначити, що критерії ефективності спиртовмісних засобів для гігієни рук відрізняються в США і Європі, що пов'язано 3 різними стандартами тестування [3]. Зокрема, спиртовмісні антисептики для обробки рук, які відповідають вимогам FDA, не обов'язково будуть відповідати критеріям європейського стандарту EN 1500 [4].

У даний час остаточно не встановлено рівень деконтамінації рук, який дозволяє мінімізувати ймовірність контактного шляху передачі патогенних мікроорганізмів в $3 \mathrm{O}$ [3]. Потребує додаткових досліджень визначення, чи слід досягати зниження мікробного числа шкіри рук на $1 \lg$ (зниження на 90\%), $2 \lg$ (на 99\%), $3 \lg$ (на 99,9\%) або $4 \lg$ (на 99,99\%).

\section{Література:}

1. Martone W.J., Jarvis W.R., Culver D.H., Haley R.W. Incidenceandnatureofendemicandepidemicnosocomialinfections. In: Bennett JV, Brachman PS, eds. HospitalInfections. 3rd ed. Boston: Little, BrownandCo; 1992. p. 577-96.

2. Boyce J.M., Potter-Bynoe G., Dziobek L. Hospitalreimbursementpatternsamongpatientswithsurgicalwoundinfectionsf ollowingopenheartsurgery. InfectControlHospEpidemiol 1990;11(2):89-93.

3. Poulsen K.B., Bremmelgaard A., Sorensen A.I., Raahave D., Petersen J.V. Estimatedcostsofpostoperativewoundinfections. A casecontrolstudyofmarginalhospitalandsocialsecuritycosts. EpidemiolInfect 1994;113(2):283-95.

4. Vegas A.A., Jodra V.M., Garcia M.L. Nosocomialinfectioninsurgerywards: a controlledstudyofincreasedduration of hospital staysanddirectcostofhospitalization. Eur $\mathrm{J}$ Epidemiol 1993;9(5):504-10. 